\title{
Pre-service and In-service Teachers' Perceptions about Using Web 2.0 in Education
}

\author{
Recep Cakir ${ }^{*}$ \\ Amasya University, Faculty of Education, Department of Computer Education \& \\ Instructional Technology,Amasya
}

Erman Yukselturk

Klrlkkale University, Faculty of Education, Department of Computer Education \& Instructional Technology, Kirlkkale

\author{
Ercan Top \\ Abant Izzet Baysal University, Faculty of Education, Department of Computer Education \& \\ Instructional Technology, Bolu
}

\begin{tabular}{|c|c|}
\hline Article history & was to examine teachers' perceptions \\
\hline $\begin{array}{l}\text { Received: } \\
13.04 .2015\end{array}$ & $\begin{array}{l}\text { about educational technologies, usage frequencies of Web } 2.0 \\
\text { technologies, and awareness of these technologies in education. }\end{array}$ \\
\hline $\begin{array}{l}\text { Received in revised form: } \\
18.06 .2015\end{array}$ & $\begin{array}{l}516 \text { pre-service ( } 308 \text { male and } 208 \text { female) who enrolled CEIT } \\
\text { departments in education faculties and } 317 \text { in-service }(229 \text { male }\end{array}$ \\
\hline $\begin{array}{l}\text { Accepted: } \\
29.06 .2015\end{array}$ & $\begin{array}{l}\text { and } 88 \text { female) ICT teachers who serve in public and private } \\
\text { primary schools participated in this study. Three instruments were }\end{array}$ \\
\hline Key words: & $\begin{array}{l}\text { used for data collection purposes. These instruments included the } \\
\text { Views of Educational Technology Scale (VETS), developed by }\end{array}$ \\
\hline $\begin{array}{l}\text { Perceptions about educational } \\
\text { technologies; Web 2.0; social } \\
\text { media in education; teacher } \\
\text { education, }\end{array}$ & $\begin{array}{l}\text { Gomleksiz (2004), the Usage of Web } 2.0 \text { Scale (UWS), developed } \\
\text { by Ajjan and Hartshorne (2008) developed by the researchers, and } \\
\text { the Awareness of Web } 2.0 \text { Scale (AWS). Descriptive survey } \\
\text { methods was used in this study to collect data. The results of the } \\
\text { study showed that the teachers had highly positive feelings about } \\
\text { the educational technology usage. The in-service teachers' views } \\
\text { about educational technology were more positive than those of the } \\
\text { pre-service teachers. Besides, the pre-service teachers' scores of } \\
\text { attitudes towards and perceived usefulness of Web } 2.0 \text { technologies } \\
\text { were higher than those of the in-service teachers. It might be } \\
\text { suggested that the views of school administrators, university } \\
\text { administrators, and faculty members in teacher training programs } \\
\text { might be investigated to determine and evaluate the impact of Web } \\
2.0 \text { technologies in a broader sense through various perspectives. }\end{array}$ \\
\hline
\end{tabular}

\footnotetext{
* Correspondence: recepcakir@gmail.com
} 


\section{Introduction}

In the past decade, Web technologies have affected not only where we learn but also what we learn and how we learn. Initially, these technologies were seen as educational and communicational resources similar to the traditional classroom resources. Web contents used to be designed hierarchically and mostly supplied by a limited number of people. Students were mainly browsing or accessing information from web pages and sharing limited knowledge through asynchronous text-based web tools (Greenhow et al., 2009; Hartshorne \& Ajjan, 2009). However, nowadays it is seen that Web technologies offer a variety of new opportunities for students and teachers that are different from what has been extensively experienced in the past (Evans \& Powell, 2007; Uzunboylu, Bicen \& Cavus, 2011). These new technologies facilitate interaction, active participation, reflection, critical thinking, role playing, and collaboration among participants. In other words, Web is not just an information resource anymore; rather it is a platform of information exchange now (Ajjan\& Hartshorne,2008; An\& Williams, 2010; Conole \& Alevizou, 2010).

Recently, a major revolution has occurred in the way Web technology is being used in several settings. It is not a technical revolution, but it is a social revolution (An \& Williams, 2010; Conole \& Alevizou, 2010; Voithofer, 2007). The new social sharing platform is transforming the Web technology in important ways: from Web 1.0 (read only) environment to Web 2.0 (both read and write) technologies (Anderson, 2007; Greenhowet al., 2009). Web 2.0 has the potential to design more interactive environments in which users become content developers, producers, editors, and evaluators. In other words, these new technologies change how contents are developed, used, shared, and distributed, and make sharing these contents among members and participants much easier than it was in the past (An \& Williams, 2010; Conole \& Alevizou, 2010).

Web 2.0 offers several powerful digital and also social media technologies that support participation and interaction in various digital formats. Blogs, wikis, podcasting, social bookmarking, and social networking tools are some examples of them. Today's students are growing up by using these technologies and they are considered as "digital natives". They have spent their whole lives surrounded by and using computers, cell phones, and all these Web 2.0 technologies (Davies, 2012; Prensky, 2001). With the help of these technologies, students can easily create information individually or as a group and share it with others. Although these technologies are not designed specifically for use in teaching and learning, they have various characteristics that provide opportunities for student publication, support active and social learning, and enhance effective and efficient feedback to learners in educational settings (Albion, 2008; Wheeler\& Wheeler, 2009).

Several researchers have emphasized that the development and growth of new Web 2.0 technologies offer new benefits to education at all levels (e.g. Anderson, 2007; Bennett et al., 2012; Bull et al., 2008; Ulrich et al., 2008; Voithofer, 2007).In spite of their popularity and advantages, these technologies have many challenges. One of the most important challenges concerns the teachers who have difficulty trying to guide and scaffold students using these technologies in their teaching environment. Roblyer et al. (2010) investigated the adoption of social networks by students and instructors and their willingness to transfer their use of these tools from the social life to the educational environment. They found that students were more likely than instructors to use social networks and were significantly more inclined to use these technologies to support their learning. As a result, teachers as digital immigrants seem to be aware of these new technologies, but, generally they might not have much knowledge about how to use them effectively while integrating them into their teaching settings (Moore \& 
Chae, 2007). In this respect, teachers are expected to co-learn, model, and facilitate the development of several digital and social competencies to be able to cope with these digital natives. In other words, teachers' digital literacy level about Web 2.0 technologies should not be less than students' level to be able to meet these new competencies. Accordingly, more research is needed to explore how and what teachers could do to educate digital natives using these new social web technologies (Schwartz \& Digiovanni, 2009; Scott \& Ryan, 2009).

\section{Web 2.0 as Digital and Social Media in Teacher Education}

Web 2.0 technologies, having emerged in 2000s, have gained the attention of many people from various areas including business, sports, health and also education over the last few years. Nowadays, Web 2.0 technologies are being used by millions of people in an active way. For example, in March 2012, Facebook became the most visited website in the world with more than 835 million users, reaching 35\% of Internet users (internet world stats, 2012). YouTube became the second with 800 million unique visitors in each month, reaching $33 \%$ of internet users (youtube statistics, 2012). Besides, Wikipedia have450 million users, reaching 19\% of Internet users (Wikipedia: Statistics, 2012). Moreover, there are 152 million blogs on the internet, and $80 \%$ of active internet users visit social networks and blogs (Cara, 2012). Similarly, the OECD (2007) report showed that $85.2 \%$ of the US higher education students were using social networking sites daily and $84.1 \%$ of them were using text messaging daily. As reflected in these statistics, Web 2.0 technologies have become very common among people thanks to their characteristics such as, accessibility, usability, functionality, and flexibility. Therefore, it is difficult for educators to ignore this fact and avoid using these technologies (Ajjan \& Hartshorne, 2008; An \& Williams, 2010; Anderson, 2007).

Moreover, there has been a growing trend to incorporate Web 2.0 technologies into the educational environments due to the possible pedagogical benefits of these technologies such as student publication, active learning, and social learning (Albion, 2008; Ferdig, 2007). Several researchers have agreed that these technologies cause a paradigm shift in teaching and learning environments from the isolated individuals to the communities of practice where collective and cooperative processes are important (e.g. Albion, 2008; Attwell 2007; Evans \& Powell, 2007). These technologies are not only the consumers of knowledge, but also the producers of it (Bull et al., 2008; Maloney, 2007). All these are in line with modern educational theories such as social constructivism and connectionism (Cifuentes et al., 2010; Conole \& Alevizou, 2010; Ulrich et al., 2008), and for that, they have been used or planned to be usedin educational settings by both pre-service and in-service teachers.

In literature, researchers agreed that both pre-service and in-service teachers' perceptions should be investigated to incorporate and adapt new digital and social technologies into the classroom environments (e.g. Baltaci-Goktalay \& Ozdilek, 2010; Coutinho, 2009; Scott \& Ryan, 2009). As examples for pre-service teacher studies, Baltaci-Goktalay \& Ozdilek (2010 pointed out that participants' perceptions about Web 2.0 technologies were positive and also their acceptance of these technologies and willingness to use them were high. Wassell and Crouch (2008) stated that the blogging environment promoted dialogue, served the participants as a tool to think critically about current issues and debates, and fostered the active expression of thoughts among the participants. Similarly, Lai and $\mathrm{Ng}$ (2011) emphasized that wiki usage helped them to develop various skills, such as instructional technology skills, collaboration skills, and organizational skills. Kabilanet al.(2009) investigated Facebook as a useful and meaningful learning environment in English language learning. According to their results, the participants believed that Facebook could be utilized 
as an online environment to enhance their learning abilities. Similar to pre-service teachers, research showed that in-service teachers using Web2.0 technologies in education have reported positive attitude and feelings. For instance, Coutinho (2009) investigated the integration of technology in Web 2.0 enriched environments for teacher education programs. She came up with the idea that technology rich training environments develop positive attitudes towards technologies among the participants and encourage them to develop constructivist learning environments in their teaching settings. Likewise, Loving et al. (2007) examined the use of blogging among teachers and found that most of their participants valued blogging for sharing resources and thoughts and reflecting on personal experiences. Every, Garcia and Young (2010) investigated student reactions to a wiki assignment given in a graduate teacher education course. They reported that after the initial phase of developing documents in the wiki interface, participants' reactions were mainly positive, with many identifying the benefits of wikis in learning environment as a resource or collaborative tool. Mazeret al.(2009) pointed out that the participants gave higher levels of credibility to the teachers who put high self-disclosure in their Facebook website.

Despite having positive feelings, teachers have also been faced with several challenges while integrating Web2.0 technologies into their educational settings. One of the most important challenges focuses on the limited models and strategies for effective integration of these technologies in teaching (Albion, 2008; Attwell, 2007; Grant \& Mims, 2009; Hew \& Brush, 2007; Redecker \& Punie, 2010). As Albion (2008) pointed out teacher education programs need to develop appropriate models and strategies to incorporate Web 2.0 technologies in teaching environments. Besides that, Grant and Mims (2009) indeed categorized such challenges regarding the use of Web 2.0 applications and their implications for teaching and learning into five categories of limitations including (a) immature applications, (b) longevity of applications, (c) limited number of applications (d) unconsolidated services and (e) issues concerning security and ethics. Although these technologies benefit both teachers and their students in various respects, many teachers still have little or no experience with Web 2.0 technologies. In other words, pre-service teachers, who are generally digital natives, are being educated with these new technologies surrounding them, but, in-service teachers, who are generally digital immigrants, are trying to incorporate these technologies to their classrooms. It means that they might have different perceptions of the benefits of using Web 2.0 applications (Coutinho, 2009; Scott \& Ryan, 2009). By examining both pre-service and inservice teachers` perceptions of using web 2.0 technologies, not only will this study fill a void that currently exists in the research (Albion, 2008; Lai \& Ng, 2011; Mazeret al., 2009), but it will also be useful in adapting web 2.0 technologies into learning environments. As a result, the following research questions guided this study:

1) What are the pre-service and in-service teachers 'views on using Education Technology?

2) What are the pre-service and in-service teachers' usage frequencies of Web 2.0 technologies?

3) What is the pre-service and in-service teachers` awareness towards Web 2.0 technologies in education?

4) Is there any significant difference between pre-service and in-service teachers' perceptions in terms of views, usage frequency, and awareness of web 2.0 technologies in education? 


\section{Method}

This study is a descriptive study focusing on pre-service and in-service ICT (Information and Communication Technologies) teachers perceptions about Web 2.0 technologies as digital and social media in their class environments.

\section{Description of ICT teachers in Turkey}

Departments of the Computer Education and Instructional Technologies (CEIT) have been established in order to educate ICT teachers for schools in Turkey (HEC, 1998). These departments, established within the education faculties, enrolled their first students in the 1999 academic year. ICT teachers who graduated from these departments are mainly working in both public and private schools. Their main responsibilities are integrating technology into classrooms and mentoring other teachers' use of technology. In other countries, it is seen that the title or the roles of the teachers who are mainly responsible for integrating technology vary from one country to another; they might have such roles as computer coordinators, technology coordinators and media specialists (Law \&Plomp, 2003). In France, for example, the government decided that all schools have computer coordinators who help teachers while integrating technology into their teaching practices (Reigner, 2003).

\section{Participants}

The subjects of the study were selected from pre-service teachers $(\mathrm{N}=516)$ who enroll at the CEIT departments, in Education Faculties, in 14 different universities, and in-service ICT teachers $(\mathrm{N}=317)$ who serve in public and private primary schools, high schools, and vocational high schools. Table 1 shows the characteristics of the pre-service and in-service teachers.

Table 1: The Characteristics of the Pre-Service and In-Service Teachers
\begin{tabular}{lcccc} 
& Pre- & In-Service \\
& Service & & \\
& $\mathrm{N}$ & $\%$ & $\mathrm{~N}$ & $\%$ \\
\hline Gender & 308 & 60 & 229 & 72 \\
Male & 208 & 40 & 88 & 28 \\
Female & 493 & 96 & 310 & 98 \\
Having a personalcomputer & 23 & 4 & 7 & 2 \\
Yes & & & & \\
No & 17 & 3 & 4 & 1 \\
Weekly internet usage & 90 & 17 & 31 & 10 \\
Lessthanonehour & 99 & 19 & 48 & 15 \\
Between 2-5 hours & 310 & 61 & 234 & 74 \\
Between 6-10 hours & & & & \\
Morethan 10 hours & & & & \\
\hline
\end{tabular}

\section{Instruments}

Three instruments were used for data collection purposes. These instruments included the Views of Educational Technology Scale (VETS), the Usage of Web 2.0 Scale (UWS), and the Awareness of Web 2.0 Scale (AWS).

The Views of Educational Technology Scale (VETS) was adapted from a questionnaire developed by Gomleksiz (2004). In order to evaluate the clarity and relevance of the items, the adapted questionnaire was reviewed by two experts in the instructional technology field. 
The questionnaire consisted of 5 five-point Likert scale items which sought to measure teachers' views on using educational technology. The reliability of the original sub-scale was determined to be high, 0.81 (Gomleksiz, 2004). In this study, the Cronbach alpha internal consistency coefficient was 0.71 .

The Usage of Web 2.0 Scale (UWS) was developed by the researchers. The scale consisted of 5five-point Likert scale items, including a not applicable choice as well, from 1(rarely - less than an hour a week) to 5 (very frequently - more than 10 hours a week) which sought to measure teachers` perceptions about their usage frequencies of seven most common Web 2.0 technologies (see Table 3) in their personal life. The reliability of the scale was determined to be high, 0.79 .

The Awareness of Web 2.0 Scale (AWS) was originally developed by Ajjan and Hartshorne (2008), consisting of items exploring participants' comfort level with Web 2.0 technologies, their actual usage of specific Web 2.0 technologies in the classroom, and their attitudes toward specific Web 2.0 technologies in education. In this study, the four sub-scales (ease of use, compatibility, attitude, and perceived usefulness) were adapted to measure teachers` awareness towards Web 2.0 technologies in education. Similar to the VETS, this scale was reviewed by two experts in the instructional technology field to evaluate the clarity and relevance of the items. Ajjan and Hartshorne (2008) reported the internal consistency coefficient as 0.90 for the ease of use scale, 0.91 for the compatibility scale, 0.93 for the attitude scale, and 0.95 for the perceived usefulness scale. In this study, the internal consistency coefficient, Cronbach alpha, was computed as 0.68 for the ease of use scale, 0.83 for the compatibility scale, 0.83 for the attitude scale, and 0.91 for the perceived usefulness scale respectively.

\section{Data Collection}

Pre-service and in-service ICT teachers were asked to participate in this study at the end of the fall term of 2010. They were informed that their participation would be voluntary and they had the right not to participate. 14 Turkish universities' Education Faculties were requested to access their pre-service teachers and these teachers were invited by these contact faculties through a mailing list. In addition, in-service teachers were accessed during a national training conference and through in-service teacher national web communities (Facebook and onlineforums). During the last two months of the fall term, both groups of ICT teachers were asked to anonymously complete the three online surveys (VETS, UWS, and AWS).

\section{Data Analysis}

The data gathered through the three online questionnaires were analyzed by descriptive analysis (e.g., means, standard deviations, and percentiles) and multivariate analysis (MANOVA) to examine the differences between pre-service and in-service teachers' perceptions about Web 2.0 technologies in their class environments by using the statistical analysis software SPSS 16.0. 


\section{Results}

\section{Descriptive Analysis}

Table 2, Table 3, and Table 4 present the descriptive statistics (mean, standard deviation) for the ICT teachers views on using educational technology, their Web 2.0 technologies usage frequencies, and their awareness of Web 2.0. According to Table 2, both the pre-service and the in-service teachers strongly agreed to the statements expressing views on using technology in the teaching environment ( $\mathrm{M}=4.3$ and $\mathrm{M}=4.5$ respectively).

Table 2: The Teachers`Views on Using Educational Technology

\begin{tabular}{|c|c|c|c|c|c|c|}
\hline & \multicolumn{3}{|c|}{ Pre-Service } & \multicolumn{3}{|c|}{ In-Service } \\
\hline & $\mathrm{N}$ & M & Std & $\mathrm{N}$ & M & Std \\
\hline $\begin{array}{l}\text { I am interested in using education technology in the } \\
\text { classroom. }\end{array}$ & 516 & 4.7 & 0.8 & 317 & 4.7 & 0.8 \\
\hline $\begin{array}{l}\text { I would like to learn more about new developments in } \\
\text { education technology. }\end{array}$ & 516 & 4.6 & 0.7 & 317 & 4.7 & 0.8 \\
\hline $\begin{array}{l}\text { Students pay more attention when I use technology in } \\
\text { the class }\end{array}$ & 516 & 4.3 & 0.8 & 317 & 4.4 & 0.9 \\
\hline I have enough knowledge for using technological aids. & 516 & 4.0 & 1.0 & 317 & 4.4 & 1.0 \\
\hline $\begin{array}{l}\text { I follow new developments in education technology } \\
\text { properly. }\end{array}$ & 516 & 3.9 & 0.9 & 317 & 4.3 & 0.9 \\
\hline Average & 516 & 4.3 & 0.6 & 317 & 4.5 & 0.6 \\
\hline
\end{tabular}

Table 3 shows the ICT teachers` usage frequencies of Web 2.0 technologies. The pre-service teachers generally preferred to use social networking, RSS and syndication, collaborative authoring, and multimedia sharing. On the other hand, the in-service teachers mainly favoured using social networking, collaborative authoring, and multimedia sharing.

Table 3: The Teachers`Web 2.0 Technologies Usage Frequencies

\begin{tabular}{|c|c|c|c|c|c|c|c|c|}
\hline & \multicolumn{4}{|c|}{ Pre-Service } & \multicolumn{4}{|c|}{ In-Service } \\
\hline & $\mathrm{N}$ & $\%$ & M & Std & $\mathrm{N}$ & $\%$ & M & Std \\
\hline Social Networking (i.e. Facebook, MySpace) & 516 & 4.3 & 3.8 & 1.3 & 317 & 7.6 & 3.2 & 1.6 \\
\hline RSS and Syndication (i.e. Google Reader) & 516 & 10.1 & 3.4 & 1.4 & 317 & 10.4 & 2.4 & 1.4 \\
\hline $\begin{array}{l}\text { Collaborative Authoring (i.e. Wikipedia, } \\
\text { GoogleDocs) }\end{array}$ & 516 & 7.4 & 3.3 & 1.3 & 317 & 5.7 & 3.1 & 1.3 \\
\hline Multimedia Sharing (i.e. Flickr, YouTube) & 516 & 5.6 & 3.3 & 1.3 & 317 & 4.7 & 2.9 & 1.3 \\
\hline $\begin{array}{l}\text { Audio Blogging and Podcasting (i.e. } \\
\text { iTunes,MeVio) }\end{array}$ & 516 & 21.5 & 2.2 & 1.3 & 317 & 11.4 & 2.0 & 1.2 \\
\hline Blogging (i.e. Blogcu.com, Blogger.com) & 516 & 13.4 & 2.1 & 1.2 & 317 & 9.5 & 2.2 & 1.4 \\
\hline Tagging and Social Bookmarking (i.e. & 516 & 12.6 & 1.9 & 1.2 & 317 & 13.9 & 2.0 & 1.2 \\
\hline Average & 516 & & 2.6 & 1.0 & 317 & & 2.3 & 1.0 \\
\hline
\end{tabular}

Table 4 shows the ICT teachers` awareness towards Web 2.0 technologies in regard to ease of use, compatibility, attitude and perceived usefulness. The pre-serviceteachers' overall mean scores for these variables were $\mathrm{M}=3.9, \mathrm{M}=3.9, \mathrm{M}=4.1$, and $\mathrm{M}=4.1$. Moreover, the in-service teachers' overall mean scores for these variables were $\mathrm{M}=3.9, \mathrm{M}=3.8, \mathrm{M}=4.0$, and $\mathrm{M}=3.9$ respectively. 
Table 4: The Teachers`Awareness Towards Web 2.0 Technologies in Education

\begin{tabular}{|c|c|c|c|c|c|c|}
\hline & \multicolumn{3}{|c|}{ Pre-Service } & \multicolumn{3}{|c|}{ In-Service } \\
\hline & $\mathrm{N}$ & M & Std. & $\mathrm{N}$ & M & Std. \\
\hline \multicolumn{7}{|l|}{ Ease of use } \\
\hline I feel that using Web 2.0 will be easy & 516 & 3.9 & 0.9 & 317 & 4.0 & 0.9 \\
\hline $\begin{array}{l}\text { I feel that using Web } 2.0 \text { will be easy to incorporate in } \\
\text { my classroom environment }\end{array}$ & 516 & 3.8 & 0.8 & 317 & 3.8 & 1.0 \\
\hline Compatibility & 516 & 3.9 & 0.7 & 317 & 3.9 & 0.8 \\
\hline $\begin{array}{l}\text { Using Web } 2.0 \text { technologies are compatible with the way } \\
\text { I teach }\end{array}$ & 516 & 3.9 & 0.8 & 317 & 3.8 & 0.9 \\
\hline Using Web 2.0 technologies fit well with the way I teach & 516 & 3.9 & 0.8 & 317 & 3.8 & 0.9 \\
\hline Attitude & 516 & 3.9 & 0.8 & 317 & 3.8 & 0.9 \\
\hline Web 2.0 is useful in my teaching & 516 & 4.2 & 0.7 & 317 & 4.0 & 0.9 \\
\hline Using Web 2.0 is a good idea & 516 & 4.2 & 0.8 & 317 & 4.0 & 0.9 \\
\hline $\begin{array}{l}\text { The advantage of using Web } 2.0 \text { outweighs the } \\
\text { disadvantages of not using it }\end{array}$ & 516 & 4.0 & 0.9 & 317 & 3.9 & 1.0 \\
\hline Perceived usefulness & 516 & 4.1 & 0.7 & 317 & 4.0 & 0.8 \\
\hline I feel that using Web 2.0 will improve students' grades & 516 & 4.1 & 0.8 & 317 & 3.9 & 0.9 \\
\hline $\begin{array}{l}\text { To help my students better learn the material, I will } \\
\text { incorporate Web } 2.0 \text { technologies in the classroom }\end{array}$ & 516 & 4.1 & 0.8 & 317 & 3.8 & 1.1 \\
\hline $\begin{array}{l}\text { I feel that using Web } 2.0 \text { will help my students learn } \\
\text { more about the subject }\end{array}$ & 516 & 4.0 & 0.8 & 317 & 3.9 & 0.9 \\
\hline $\begin{array}{l}\text { I feel that using Web } 2.0 \text { will improve students' } \\
\text { satisfaction with the course }\end{array}$ & 516 & 4.0 & 0.8 & 317 & 4.0 & 0.9 \\
\hline $\begin{array}{l}\text { I feel that using Web } 2.0 \text { will improve students' } \\
\text { evaluation }\end{array}$ & 516 & 4.0 & 0.8 & 317 & 3.9 & 0.9 \\
\hline Average & 516 & 4.1 & 0.7 & 317 & 3.9 & 0.8 \\
\hline
\end{tabular}

\section{Multivariate Analysis}

A one-way MANOVA was conducted to determine the effect of teacher status (pre-service and in-service) on the teachers perceptions about Web 2.0 technologies. Assumptions of MANOVA was tested to check for normality, linearity, homogeneity of variance-covariance matrices, and multi collinearity with no serious violations noted in either of the test scores. Also, outlier analysis was conducted and 22 outliers were removed from the dataset. The results showed that significant differences were found between the pre-service and the inservice ICT teachers' perceptions on dependent measures (Wilks' $\Lambda=0.882, \mathrm{~F}(6,803)=17.84$, $\mathrm{P}<.001)$. The multivariate $\eta 2$ based on Wilks' $\Lambda$ was strong, 0.118 .

Analyses of variances (ANOVA) on each dependent variable were conducted as follow-up tests to the MANOVA. All tests were significant at the 0.05 level, except for ease of use and compatibility variables. Table 5 summarizes the significant ANOVA results. The in-service teachers 'views on using educational technology were significantly more positive than those of the pre-service teachers $(\mathrm{F}(1,808)=34.774, \mathrm{p}<0.01, \eta 2=.041)$. On the other hand, the preservice teachers`Web 2.0 technologies usage frequencies $(\mathrm{F}(1,808)=12.642, \mathrm{p}<0.01$, 
$\eta 2=.015)$, their scores of attitudes towards these tools $(F(1,808)=11.681, p<0.01, \eta 2=.014)$ and their scores of these tools' perceived usefulness $(F(1,808)=10.582, p<0.01$, $\eta 2=.013)$ were higher than those of the in-service teachers.

Table 5: Post Hoc Anova Test Result

\begin{tabular}{lllll}
\hline Dependent Variable & df & $\mathrm{F}$ & $\eta^{2}$ & $\mathrm{p}$ \\
\hline Views on using Educational Technology & 1 & 34.774 & .041 & $.000^{*}$ \\
Web 2.0 technologies usage frequency & 1 & 12.642 & .015 & $.000^{*}$ \\
Ease of use & 1 & .000 & .000 & .991 \\
Compatibility & 1 & 1.648 & .002 & .200 \\
Attitude & 1 & 11.681 & .014 & $.001^{*}$ \\
Perceivedusefulness & 1 & 10.582 & .013 & $.001^{*}$ \\
\hline
\end{tabular}

$$
* \mathbf{p}<\mathbf{0 . 0 5}
$$

\section{Discussion}

Web 2.0 technologies, causing a cultural change in terms of communication, knowledge, and information in various areas, are used globally as sharing media by more than a billion people (Anderson, 2007). Similarly, the use of educational technologies to support teaching and learning has changed over the last decade with the increased functionality and popularity of Web 2.0 technologies, which have various potentials to improve teaching and learning (Hartshorne \& Ajjan, 2009). These technologies bring new roles, new pedagogies, and new approaches to today's teachers. In order to develop such innovations and integrate them into the learning and teaching environments, researchers state that views, competencies, and awareness levels of the teachers who incorporate these technologies into their classes need to be analyzed and enhanced (Albion, 2008; Coutinho, 2009; Greenhowet al.,2009; Moore \& Chae, 2007). Therefore, this study was designed to examine both pre-service and inservice teachers` perceptions of using web 2.0 technologies.

In this study, the teachers had highly positive feelings about the use of educational technology. They were highly interested in learning new educational technologies and using these technologies in their classrooms. Similarly, in the literature, there has been a growing trend to incorporate new technologies into the educational environments due to their provision of various opportunities (e.g. accessibility, ease of use, and functionality) and their possible pedagogical benefits (e.g. active learning, and social learning) (Albion, 2008; Bull et al., 2008; Moore \& Chae, 2007). In their personal life, social networking, such as Facebook, and collaborative authoring technologies, such as Wikipedia were mainly used by the teachers in this study. In other words, almost $95 \%$ of the teachers had access to these two technologies. This result was parallel to the public Web 2.0 technologies usage frequencies (Ionescu, 2010) and other university students' Web 2.0 technology usage frequencies (e.g. OECD, 2007). The results also showed that the teachers were generally aware of Web 2.0 technologies' benefits in educational settings, and, they did not have much difficulty while using and adapting these new technologies to their teaching.

Although the teachers 'views about using educational technology and their awareness towards Web 2.0 technologies in education were positive, there were some differences between the pre-service and the in-service teachers` perceptions about Web 2.0 technologies. For example, the results showed that the in-service teachers' scores on their views about using educational technology were higher than those of the pre-service teachers'; however, they were using these technologies less frequently than the pre-service teachers. The reason behind might be that the teachers who have actual teaching experience using educational technologies have 
become more aware of the possibilities and the implications of integrating them into their teaching (Voithofer, 2007). Moreover, the pre-service teachers' scores of attitudes towards Web 2.0 technologies and their scores of these tools' perceived usefulness were higher than those of the in-service teachers. This interesting result might be due to the gap between the training in university and the real life practices (Bull et al., 2008). Also, several researchers have agreed that there might be some barriers to the effective integration of these new technologies into classroom such as the deficiencies of Web 2.0 technologies themselves (e.g. immaturity, longevity and security) and the pedagogical deficiencies (e.g. lack of familiarity with how to use these technologies and lack of educational theories regarding how to design technology-compatible teaching and learning environments) (e.g. Albion, 2008; Attwell, 2007; Grant\&Mims, 2009; Greenhowet al.,2009).

This study mainly showed that Web 2.0 technologies are common among the investigated teachers. They were generally aware of these technologies and their potential uses in educational environments. The teachers participated in this study agreed on adapting educational technologies and benefiting from them while designing their lessons and classroom environments. However, it did not show that they used all new Web 2.0 technologies frequently in their personal and/or professional lives. Actually, they used some of them often, but, some of the applications were used very rarely, such as, social bookmarking, podcasting, and blogging. Like with many new educational technologies, teachers need to see how these technologies are designed and used effectively (Coutinho, 2009). Especially, pre-service teachers' beliefson educational technologies could be enhanced by increasing their teaching experience in real teaching contexts (Voithofer, 2007) or by increasing the use of web 2.0 technologies in universities to provide students with an opportunity to experience such processes themselves (Bull et al., 2008; Sendallet al.,2010). The study also showed that the in-service teachers' awareness about Web 2.0 technologies was less than that of the pre-service teachers. This, in fact, could be enhanced by providing institutional support, aligning curricula accordingly, or providing regular teacher training sessions (Hew \& Brush, 2007; Redecker \& Punie, 2010).

\section{Conclusion}

Over the last few years, Web 2.0 technologies have been changing how people access and exchange knowledge and information, and how people connect and interact in various areas, like in education (Ajjan \& Hartshorne, 2008; An \& Williams, 2010; Redecker \& Punie, 2010). Teachers and their students, both of whom are already using these technologies in their personal lives, are also feeling under pressure to use these technologies in their educational environments. For that reason, the number of studies about the use and adaptation of Web 2.0 technologies in education has increased in recent years (Albion, 2008; Hartshorne \& Ajjan, 2009; Voithofer, 2007). Similarly, teachers perceptions about educational technologies, usage frequencies of Web 2.0 technologies, and awareness of these technologies in education were investigated in this study. According to the results, teachers had highly positive feelings about the educational technology usage and their awareness towards Web 2.0 technologies in education was also high. They mainly preferred to use some Web 2.0 technologies more often, such as social networking in their personal lives. There were also some differences between the pre-service and in-service teachers 'perceptions about the Web 2.0 technologies. The in-service teachers' views about educational technology were more positive than those of the pre-service teachers. However, they were using Web 2.0 technologies less frequently than the pre-service teachers. Moreover, the pre-service teachers' 
scores of attitudes towards and perceived usefulness of Web 2.0 technologies were higher than those of the in-service teachers.

Although there are several studies related to the use of digital and social media technologies in education, as the results of this study show, several researchers agree that there is still a need for more in-depth studies to increase the potential benefits of these technologies (Hartshorne \& Ajjan, 2009; Lai \& Ng, 2011).Especially, there is a need to examine teachers` experiences and perceptions since they are the real implementers and decision makers when adapting these technologies in teaching-learning environments. This study analyzed both the pre-service and in-service teachers ' perceptions, but, it had several limitations. For example, the participants of this study were ICT teachers who might have been more inclined towards using these technologies in their classes and personal lives than teachers of other subject matters. That might weaken the generalizability of the results though the number of participants in the study was adequate. Accordingly, the study could be replicated with teachers of other subject matters as well. Also, future research is still necessary in order to really observe teachers when applying Web 2.0 technologies into their courses. Besides, in another study, it might be interesting to examine how gender, weekly internet usage, age, or other demographic variables contribute to teacher perceptions. Moreover, the views of school administrators, university administrators, and faculty members in teacher training programs might be investigated to determine and evaluate the impact of Web 2.0 technologies in a broader sense through various perspectives.

\section{References}

Ajjan, H.\& Hartshorne, R. (2008). Investigating faculty decisions to adopt Web 2.0 technologies: Theory and empirical tests. Internet and Higher Education, 11(2), 7180 .

Albion, P. R. (2008). Web 2.0 in teacher education: Two imperatives for action. Computers in the Schools, 25(3/4), 181-198.

An, Y.J. \& Williams, K. (2010). Teaching with Web 2.0 technologies: Benefits, barriers and lessons learned. International Journal of Instructional Technology and Distance Learning, 7(3), 41-48.

Anderson, P. (2007). What is Web 2.0? Ideas, technologies and implications for education.Technical report, JISC.Available at: http://www.jisc.ac.uk/media/documents/techwatch/tsw0701b.pdf. Accessed April 14 2015.

Attwell, G. (2007). Web 2.0 and the changing ways we are using computers for learning: What are the implications for pedagogy and curriculum? Available at: http://www.elearningeuropa.info/files/media/media13018.pdf.Accessed April 142015.

Baltaci-Goktalay, S.\&Ozdilek, Z. (2010). Pre-service teachers' perceptions about web 2.0 technologies. Procedia Social and Behavioral Sciences, 2(2), 4737-4741.

Bennett, S., Bishop, A., Dalgarno, B., Waycott, J. \&Kennedy, G., (2012). Implementing Web 2.0 technologies in higher education: A collective case study. Computers \& Education, 59(2), 524-534

Bull, G., Thompson, A., Searson, M., Garofalo, J., Park, J., Young, C., \& Lee, J. (2008).

Connecting informal and formal learning: Experiences in the age of participatory media. Contemporary Issues in Technology and Teacher Education, 8(2), 100-107. 
Cara, P. (2012,(Sebtember, 15). 216 social media and Internet Statistics. Available at: http://thesocialskinny.com/216-social-media-and-internet-statistics-september-2012/ Accessed January 102013.

Cifuentes, L., Sharp, A., Bulu, S., Benz, M., \&Stough, L. M. (2010).Developing a Web 2.0based system with user-authored content for community use and teacher education. Educational Technology Research and Development, 58(4), 377-398.

Conole, G.\&Alevizou, P. (2010).A literature review of the use of Web 2.0 tools in Higher Education. The Open University. UK. Available at: http://www.heacademy.ac.uk/assets/EvidenceNet/Conole_Alevizou_2010.pdf.Accesse d April 142015.

Coutinho, C. P. (2009). Challenges for teacher education in the learning society: Case studies of promising practice. In H. H. Yang \& S. H. Yuen (eds.) Handbook of research on practices and outcomes in e-learning: Issues and trends. (pp. 385-401). Hershey, New York: IGI Global.

Davies, J. (2012). Facework on Facebook as a new literacy practice. Computers \& Education, 59(1), 19-29

Evans, M. A. \& Powell, A. (2007). Conceptual and practical issues related to the design for and sustainability of communities of practice: The case of e-portfolio use in preservice teacher training. Technology, Pedagogy and Education, 16(2), 199-214.

Every, V., Garcia, G.,\& Young, M. (2010).A qualitative study of public wiki use in a teacher education program. In D. Gibson \& B. Dodge (Eds.), Proceedings of Society for Information Technology \& Teacher Education International Conference (pp. 55-62). Chesapeake, VA: AACE. Available at: http://homepages.uconn.edu/ vje01002/finalSITEPaperVEvery.pdf.Accessed April 14 2015.

Ferdig, R. E. (2007). Editorial: Examining social software in teacher education. Journal of Technology and Teacher Education, 15(1), 5-10.

Gomleksiz, M. N. (2004). Use of education technology in English classes. The Turkish Online Journal of Educational Technology, 3(2), 71-77.

Grant, M. M. \& Mims, C. (2009).Web 2.0 in teacher education: Characteristics, implications and limitations.In T. Kidd \& I. Chen (Eds.), Wired for learning: An educator's guide to Web 2.0 (pp. 343-360). Charlotte, NC: Information Age Publishing.

Greenhow, C., Robelia, B., \& Hughes, J. E. (2009).Learning, teaching, and scholarship in a digital age. Web 2.0 and classroom research:What path should we take" now"? Educational Researcher, 38(4), 246-259.

Hartshorne, R. \&Ajjan, H. (2009).Examining student decisions to adopt Web 2.0 technologies: Theory and empirical tests. Journal of Computing in Higher Education, 21(3), 183-198.

HEC (The Higher Education Council) (1998).Ĕ̌itim fakülteleri öğretmen yetiştirme programlarının yeniden düzenlenmesi. T.C. Yüksek öğretim Kurulu Başkanlığı. Ankara, Turkey.

Hew, K. F.\& Brush, T. (2007). Integrating technology into K-12 teaching and learning: Current knowledge gaps and recommendations for future research. Education Technology Research Development, 55(3), 223-252.

Ionescu, D. (2010, May 28). Google names Facebook most visited site. PC World. Available at:

http://www.pcworld.com/article/197431/google_names_facebook_most_visited_site.h tml.Accessed April 142014.

Internetstats (2012).Internet World Stats.2001 - 2013, Miniwatts Marketing Group.http://www.internetworldstats.com. Accessed January 152013 
Kabilan, M. K., Ahmad, N., \& Abidin, M. J. Z. (2009). Facebook: An online environment for learning of English in institutions of higher education? Internet and Higher Education, 13(4), 179-187.

Lai, Y. C.\& Ng, E. M. W. (2011). Using wikis to develop student teachers' learning, teaching, and assessment capabilities, Internet and Higher Education, 14(1), 15-26.

Law, N.\&Plomp, T.(2003). Curriculum and staff development for ICT in education. In T. Plomp, R. Anderson, N. Law, \& A. Quale (Eds.), Cross-national information and communication technology policies and practices in education (pp. 15-31). Greenwich, Connecticut: IAP.

Loving, C. C., Schroeder, C., Kang, R., Shimek, C., \& Herbert, B. (2007). Blogs: Enhancing links in a professional learning community of science and mathematics teachers. Contemporary Issues in Technology and Teacher Education, 7(3), 178-198.

Maloney, E. (2007). What Web 2.0 can teach us about learning.Chronicle of Higher Education, 25(18), 26-27.

Mazer, J. P., Murphy, R. E., \& Simonds, C. J. (2009).The effects of teacher self-disclosure via Facebook on teacher credibility. Learning, Media and Technology, 34(2), 175-183.

Moore, J. A.\&Chae, B. (2007).Beginning teachers' use of online resources and communities. Technology, Pedagogy and Education, 16(2), 215-224.

OECD (2007). Participative web and user-created content. Web 2.0, wikis and social networking. Available at: http://213.253.134.43/oecd/pdfs/browseit/9307031e.pdf.Accessed April 142014.

Prensky, M. (2001).Digital natives, digital immigrants. On the Horizon, 9(5), 1-6.

Redecker, C. \&Punie, Y. (2010).Learning 2.0 promoting innovation in formal education and training in Europe. In M. Wolpers, P. A. Kirschner, M. Scheffel, S. Lindstaedt, \& V. Dimitro (Eds.), Proceedings of 5th European Conference on Technology Enhanced Learning (pp. 308-323), Barcelona, Spain: Springer.

Reigner, C. (2003). National policies and practices on ICT in education: France. In T. Plomp, R. Anderson, N. Law, \& A. Quale (Eds.), Cross-national information and communication technology policies and practices in education (pp. 233-247). Greenwich, Connecticut: IAP.

Robyler, M. D., McDaniel, M., Webb, M., Herman, J., \& Witty, J. V. (2010). Findings on Facebook in higher education: A comparison of college faculty and student uses and perceptions of social networking sites. Internet and Higher Education, 13(3), 134-140.

Schwartz, S. \& Digiovanni, L. (2009). About, for, and with students: Connecting teaching and teacher education through digital literacy. In G. Siemens \& C. Fulford (Eds.), Proceedings of World Conference on Educational Multimedia, Hypermedia and Telecommunications (pp. 2047-2050). Chesapeake, VA: AACE.

Scott, A.\& Ryan, J. (2009). Digital literacy and using online discussions: Reflections from teaching large cohorts in teacher education. In J. Zajda \& D. Gibbs (eds.), Comparative information technology: Languages, societies and the internet. (pp. 103120). Dordrecht, Netherlands: Springer.

Sendall, P., Ceccucci, C., \& Peslak, R. P. (2010). Got Web 2.0? A review of Web 2.0 tools for the Information Systems curriculum. Information Systems Education Journal, 8(28), Available at: http://www.isedj.org/8/28/ISEDJ.8\%2828\%29.Sendall.pdf. Accessed April 142015.

Ullrich, C., Borau, K., Luo, H., Tan, X., Shen, L., \&Shen, R. (2008). Why Web 2.0 is good for learning and for research: Principles and prototypes. In WWW 2008 (pp. 705-714). Beijing, China. 
Uzunboylu, H., Bicen, H. \&Cavus, N. (2011) The efficient virtual learning environment: A case study of web 2.0 tools and Windows live spaces. Computers \& Education, 56 (3), $720-726$

Voithofer, R. (2007). Web 2.0: What is it and how can it apply to teaching and teacher preparation? Paper presented at the American Educational Research Association Conference, Chicago, IL. Conference.Available at:

http://citeseerx.ist.psu.edu/viewdoc/download;jsessionid=C7EC6A6242E3A3B4BA64 A6FFECFC8083?doi=10.1.1.94.5875\&rep=rep1\&type=pdf.Accessed April 142014.

Wassell, B. \& Crouch, C. (2008). Fostering connections between multicultural education and technology: Incorporating weblogs into preservice teacher education. Journal of Technology and Teacher Education, 16(2), 211-232.

Wheeler, S. \& Wheeler, D. (2009).Using wikis to promote quality learning in teacher training.Learning, Media and Technology,34(1), 1-10.

Wikipedia Statistics(2012).Wikipedia, the free encyclopedia, Statisticshttp://en.wikipedia.org/wiki/Wikipedia:Statistics\#Active_counters. Accessed January 162013

Youtubestatistics(2012).Youtube statistics, Viewership http://www.youtube.com/yt/press/statistics.html. Accessed December 162014. 